\title{
A Novel, Amorphous, Non-equiatomic FeCrAICuNiSi High-Entropy Alloy with Exceptional Corrosion Resistance and Mechanical Properties
}

\author{
Xigang Yang ${ }^{1} \cdot$ Yun Zhou ${ }^{2} \cdot$ Ruihua Zhu $^{1} \cdot$ Shengqi $\mathrm{Xi}^{1} \cdot$ Cheng He ${ }^{1} \cdot \mathrm{Hongjing} \mathrm{Wu}^{1} \cdot$ Yuan Gao ${ }^{1}$
}

Received: 15 August 2019 / Revised: 2 October 2019 / Published online: 6 December 2019

(C) The Chinese Society for Metals (CSM) and Springer-Verlag GmbH Germany, part of Springer Nature 2019

\begin{abstract}
The exceptional corrosion resistance and mechanical properties of high-entropy metallic glasses (HE-MGs) are highly desirable for diverse critical applications. However, a long-standing problem of these alloys is that their alloy design approaches are based on limited equiatomic or near-equiatomic ratios. In this study, a novel senary alloy (non-equiatomic $\mathrm{Fe}_{3} \mathrm{Cr}_{2} \mathrm{Al}_{2} \mathrm{CuNi}_{4} \mathrm{Si}_{5}$ ) with amorphous structure was prepared. This alloy exhibited exceptional corrosion resistance and Vickers hardness as high as $\sim 1150 \mathrm{Hv}$ at room temperature. The processing route involved amorphous powder molding via a mechanical alloying and ultrahigh pressure consolidation technique, resulting in an optimal microstructure of amorphous structure with nanoparticles uniformly distributed in the matrix alloy. This approach can effectively inhibit the crystallization of amorphous structure, thus providing a general pathway for manufacturing next-generation non-equiatomic HE-MGs with both exceptional corrosion resistance and strength.
\end{abstract}

Keywords Alloying $\cdot$ Metallic glasses $\cdot$ Corrosion resistance $\cdot$ Mechanical alloying $\cdot$ High-entropy metallic glasses

\section{Introduction}

Metallic glasses (MGs) are a type of advanced materials with long-range disorderly and short-range orderly structural features. Compared with crystalline alloys, MGs usually do not have the grain boundaries, dislocations and stacking faults, endowing them with ultrahigh fracture strength, superior elastic limit and excellent corrosion resistance [1-3]. Recently, Al-Y-Ni MGs have been prepared, exhibiting a tensile fracture strength of more than $1000 \mathrm{MPa}$ combined with good bend ductility; the tensile strength is almost two times as high as that of conventional Al-based crystalline alloys $[4,5]$. $\mathrm{Fe}-\mathrm{Cr}-\mathrm{Mo}-\mathrm{C}-\mathrm{B}$ system MGs have been sprayed as protective coatings on numerous

Available online at http://link.springer.com/journal/40195.

Shengqi Xi

1015872140@qq.com

1 State Key Laboratory for Mechanical Behavior of Materials, School of Materials Science and Engineering, Xi'an Jiaotong University, Xi' an 710049, China

2 School of Medical Information and Engineering, Southwest Medical University, Luzhou 646000, China prototypes and parts, exhibiting better corrosion and wear resistance than conventional stainless steels and $\mathrm{Ni}$-based alloys [6-8]. These performances of MGs have been proven to be of fundamental scientific interest with potential applications including drilling, shipbuilding industry and petroleum industry because of their contrast with conventional crystalline metals. Thus, MGs have attracted much attention in the past few decades. However, most MGs contain three or more elements based on the selection of one or two elements as the primary components in the current study, such as Zr-based [9], Cu-based [10] and FeB-based [11] MGs. The limited number of principal elements is in fact a well-known bottleneck that limits the development of MGs. Recently, a revolutionary alloy design concept, named highentropy alloy (HEAs), has been proposed. These alloys have high configurational entropies that can significantly reduce the Gibbs free energy and stabilize the structures. Previous studies showed that some HEAs can form an amorphous state, known as HE-MGs, and these alloys exhibit excellent comprehensive properties originating from both HEAs and MGs [12, 13]. Therefore, HE-MGs provide a new possibility for developing novel MG-forming structures or systems.

However, not all HEAs can form MG microstructures. In many cases, the formation of a single-phase solid solution 
or even complex compounds is often observed [14]. To obtain HE-MGs, multicomponent alloys with equiatomic or near-equiatomic ratios are designed to achieve a high mixing entropy. Some equiatomic HE-MGs have been reported, such as $\mathrm{Ti}_{16.7} \mathrm{Zr}_{16.7} \mathrm{Hf}_{16.7} \mathrm{Cu}_{16.7} \mathrm{Ni}_{16.7} \mathrm{Be}_{16.7}$, $\mathrm{Zr}_{20} \mathrm{Ti}_{20} \mathrm{Hf}_{20} \mathrm{M}_{20} \mathrm{Be}_{20}(\mathrm{M}=\mathrm{Cu}$, Ni and $\mathrm{Co})$ and $\mathrm{Fe}_{25} \mathrm{Co}_{25} \mathrm{Ni}_{25}$ $(\mathrm{B}, \mathrm{Si})_{25}[15,16]$. Non-equiatomic HEAs are mainly focused on solid-solution alloys with simple crystal structures (for example, $\mathrm{Cr}_{10} \mathrm{Mn}_{40} \mathrm{Fe}_{40} \mathrm{Co}_{10}$ [17] quaternary alloys, and $\mathrm{Fe}_{40} \mathrm{Mn}_{27} \mathrm{Ni}_{26} \mathrm{Co}_{5} \mathrm{Cr}_{2}$ [18] and $\mathrm{Fe}_{34} \mathrm{Cr}_{34} \mathrm{Ni}_{14} \mathrm{Al}_{14} \mathrm{Co}_{4}$ [19, 20] quinary alloys) in recent years. However, non-equiatomic HE-MGs have not been further studied so far, and their microformability is still elusive. Moreover, the HE-MG systems are quite limited, and the exploration of new HEMGs in broader alloy systems is still an unsolved challenge. In these cases, it is necessary to explore non-equiatomic HE-MG systems to develop their latent value.

Herein, a non-equiatomic and inexpensive HE-MG was designed, based on the statistical analysis of phase selection rules and similar element replacement principle. Metalloid silicon elements were added to the high-entropy alloy to improve the glass-forming ability (GFA) and lower the alloy costs. Taking FeCrAlCuNiSi alloy system as the research object, a series of FeCrAlCuNiSi alloys were designed based on the first-principles calculation, but this study only focuses on the $\mathrm{Fe}_{3} \mathrm{Cr}_{2} \mathrm{Al}_{2} \mathrm{CuNi}_{4} \mathrm{Si}_{5}$ to illustrate the proof of concept. In this study, mechanical alloying (MA) technique [21, 22] was applied to prepare $\mathrm{Fe}_{3} \mathrm{Cr}_{2} \mathrm{Al}_{2} \mathrm{CuNi}_{4} \mathrm{Si}_{5} \mathrm{HE}-\mathrm{MG}$. The microstructural evolution, corrosion resistance and mechanical properties of alloy were investigated.

\section{Experimental}

$\mathrm{Fe}, \mathrm{Cr}, \mathrm{Al}, \mathrm{Cu}, \mathrm{Ni}$ and $\mathrm{Si}$ elemental powders with high purity ( $\geq 99.9 \mathrm{wt} \%)$ and the particle size of $\leq 75 \mu \mathrm{m}$ (200 mesh) were used as the raw materials for preparing MGs. Milling was carried out for up to $40 \mathrm{~h}$ in a high-energy self-made attritor (amplitude of $15 \mathrm{~mm}$ ) at a speed of $900 \mathrm{rpm}$ with a ball-to-powder weight ratio of 60:1. High-performance hardened steel rods $(\varphi: 7.5 \mathrm{~mm}, L: 550 \mathrm{~mm}, 304$ stainless steel) were used as the milling media. The temperature of steel rods was maintained between 20 and $30{ }^{\circ} \mathrm{C}$ all the time using dynamic constant temperature water. To protect the powders from oxidation with atmospheric air, the powders were purified by low-temperature annealing, to improve the removal of adsorbed gases. Then, the hardened steel rods and as-received powders were placed in stainless steel vials. The powders were protected with argon atmosphere in the vial (with purity of 99.9\%). After the completion of milling, the $\mathrm{Fe}_{3} \mathrm{Cr}_{2} \mathrm{Al}_{2} \mathrm{CuNi}_{4} \mathrm{Si}_{5}$ high-entropy MG powders were prepared. Finally, ultrahigh pressure consolidation (UHPC) was conducted using a multiaxial hydroforming machine
(HTDS-032A) with WC anvils. The $\mathrm{Fe}_{3} \mathrm{Cr}_{2} \mathrm{Al}_{2} \mathrm{CuNi}_{4} \mathrm{Si}_{5}$ high-entropy MG (HE-MG) powders were consolidated into cylinders with an outer diameter of $10 \mathrm{~mm}$ and a thickness of $10 \mathrm{~mm}$ at a low temperature $\left(300^{\circ} \mathrm{C}\right)$ and ultrahigh pressure $(6 \mathrm{GPa})$.

For microstructural observation, the alloy specimens were ground and polished using standard metallographic techniques, the specimens were etched with a solution composed of phosphoric acid and ethanol (in a volume ratio of 1:9). The phase was identified using an X-ray diffraction (XRD) spectrometer (PANAlytical X'Pert'S-MPD, Holland) with $\mathrm{Cu}-K \alpha(\lambda=0.154056 \mathrm{~nm})$ radiation. The diffraction patterns were recorded in the $2 \theta$ range from 30 to 100 with a step size of 0.224 and a collection time of $30 \mathrm{~s}$ per step. The microstructures were characterized using a Zeiss Gemini 500 FEG scanning electron microscope (SEM) and a JEM-2100Plus $(200 \mathrm{kV})$ transmission electron microscope (TEM). The electrochemical measurements were carried out in a corrosion cell containing $150 \mathrm{~mL}$ of $3.5 \% \mathrm{NaCl}$ using a standard three-electrode configuration. The hardness measurements were carried out using a digital-type microsclerometer under a load of $1000 \mathrm{~g}$ for $15 \mathrm{~s}$.

\section{Results and Discussion}

\subsection{Phase Identification and Microstructure}

Figure 1 shows the XRD patterns of $\mathrm{Fe}_{3} \mathrm{Cr}_{2} \mathrm{Al}_{2} \mathrm{CuNi}_{4} \mathrm{Si}_{5}$ HEA powders in different milling time by MA. In the XRD patterns, the diffraction peaks of relevant alloy elements were clearly observed in 0 -h milled powders. As the MA

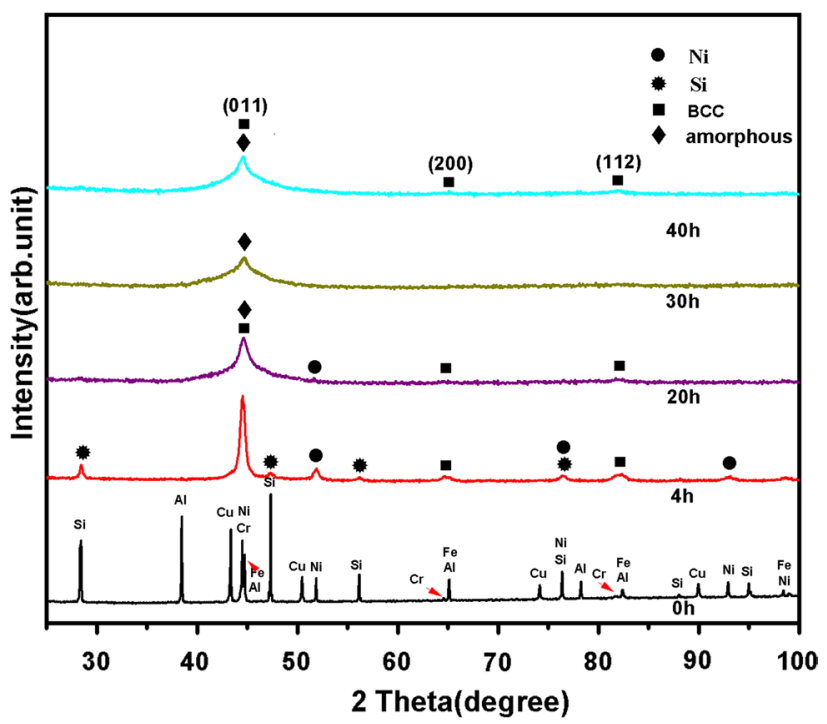

Fig. 1 XRD patterns of $\mathrm{Fe}_{3} \mathrm{Cr}_{2} \mathrm{Al}_{2} \mathrm{CuNi}_{4} \mathrm{Si}_{5}$ HEA powders in different milling time 
process proceeded, the intensities of the elemental constituent peaks rapidly decreased, suggesting that the mixing powders underwent alloying. The peaks corresponding to $\mathrm{Al}$ and $\mathrm{Cu}$ completely disappeared after milling for $4 \mathrm{~h}$, suggesting that $\mathrm{Al}$ and $\mathrm{Cu}$ had the highest alloying rate in the $\mathrm{Fe}_{3} \mathrm{Cr}_{2} \mathrm{Al}_{2} \mathrm{CuNi}_{4} \mathrm{Si}_{5}$ HEA system. When the milling time reached up to $20 \mathrm{~h}$, the majority of diffraction peaks disappeared; only the diffraction peaks of Ni still could be detected at low angles. After $30 \mathrm{~h}$ of milling, all the peaks corresponding to the constituent elements completely disappeared, and a broad peak corresponding to MG was observed. The amorphous structure was confirmed later by TEM. As the milling time further increased to $40 \mathrm{~h}$, the $\mathrm{Fe}_{3} \mathrm{Cr}_{2} \mathrm{Al}_{2} \mathrm{CuNi}_{4} \mathrm{Si}_{5}$ HE-MG powders crystallized, and only a small amount of BCC solid solution was detected by XRD. Notably, $\mathrm{Fe}_{3} \mathrm{Cr}_{2} \mathrm{Al}_{2} \mathrm{CuNi}_{4} \mathrm{Si}_{5}$ HE-MG can be obtained by MA.

The phase formation rule of HEAs was proposed by Zhang et al. [23] and Guo et al. [24]. The phase selection in HEAs can be mainly predicted by the parameters: atomic size difference $(\delta)$ and the mixing enthalpy $\left(\Delta H_{\text {mix }}\right)$. The results show that the HE-MG can be formed when $\delta \geq 0.064$ and $\Delta H_{\text {mix }} \leq-12.2 \mathrm{~kJ} / \mathrm{mol}$ [25]. In this study, the atomic radii of constituents in $\mathrm{Fe}_{3} \mathrm{Cr}_{2} \mathrm{Al}_{2} \mathrm{CuNi}_{4} \mathrm{Si}_{5}$ HEAs were significantly different, and the order of atomic radii is $\mathrm{Al}>\mathrm{Cu}>\mathrm{Cr}>\mathrm{Ni}>\mathrm{Fe}>\mathrm{Si}$. The difference in atomic radii among constituent elements, $\Delta r / r$, is the main factor influencing the glass-forming ability. According to the confusion principle [26], metalloid Si has the smallest atomic radius, i.e., $\mathrm{Si}$ is likely to infill a vacant site among the atoms in the disordered structure. This leads to the release of extra free energy, and the resulting stability favors the glass formation. Similarly, Si has highly negative heats of mixing with $\mathrm{Fe}, \mathrm{Cr}$, $\mathrm{Al}, \mathrm{Cu}$ and $\mathrm{Ni}$ of $-35,-37,-19,-19$ and $-40 \mathrm{~kJ} / \mathrm{mol}$ [27], respectively. These values are significantly larger than those for $\mathrm{Fe}-(\mathrm{Cr}, \mathrm{Al}, \mathrm{Cu}, \mathrm{Ni}), \mathrm{Cr}-(\mathrm{Al}, \mathrm{Cu}, \mathrm{Ni}), \mathrm{Al}-(\mathrm{Cu}, \mathrm{Ni})$ and $\mathrm{Cu}-\mathrm{Ni}$ atomic pairs. As a result, atomic size effect among the constituents and strong chemical affinities are helpful in enhancing the glass-forming ability of $\mathrm{Fe}_{3} \mathrm{Cr}_{2} \mathrm{Al}_{2} \mathrm{CuNi}_{4} \mathrm{Si}_{5}$ HEAs. During ball milling, the starting powders were subjected to repeated fracture and cold welding, leading to the accumulation of internal defects and stored energy, and this circulation facilitated the atomic diffusion and alloying of different metal powders [28]. Besides, a crystalline phase was formed on continued milling after the amorphous phase; this phenomenon is known as mechanical crystallization [28, 29]. Several studies on similar observations have been reported; the crystalline phase could be a metastable or equilibrium phase, formed as a result of decomposition of amorphous phase [30, 31].

The morphology of $\mathrm{Fe}_{3} \mathrm{Cr}_{2} \mathrm{Al}_{2} \mathrm{CuNi}_{4} \mathrm{Si}_{5}$ HEA powders produced at different milling time was investigated via SEM, as shown in Fig. 2. Clearly, the morphology of
$\mathrm{Fe}_{3} \mathrm{Cr}_{2} \mathrm{Al}_{2} \mathrm{CuNi}_{4} \mathrm{Si}_{5}$ HEA powders changed after MA. In the early period of milling ( $4 \mathrm{~h}$ and $8 \mathrm{~h}$, as shown in Fig. 2a, b), first the plastic deformation of powders occurred, and some soft powders were flattened. When the milling was prolonged, the powders cold-weld together to form some larger particles, as shown in Fig. 2c. Meanwhile, some undissolved small powder particles were observed, probably $\mathrm{Ni}$ and $\mathrm{Si}$. As the milling time increased to $20 \mathrm{~h}$, as shown in Fig. 2d, the force of the grinding medium made the powders harden, and some cold-welded agglomerations were crushed down to smaller particles. When the milling time reached up to $30 \mathrm{~h}$, as shown in Fig. $2 \mathrm{e}, \mathrm{Fe}_{3} \mathrm{Cr}_{2} \mathrm{Al}_{2} \mathrm{CuNi}_{4} \mathrm{Si}_{5}$ powders with an almost spherical shape were obtained, and the average particle size was about $12 \mu \mathrm{m}$. Moreover, the morphology of $\mathrm{Fe}_{3} \mathrm{Cr}_{2} \mathrm{Al}_{2} \mathrm{CuNi}_{4} \mathrm{Si}_{5}$ powders became smooth. The powder particles crushed down again to smaller particles when the milling time reached $40 \mathrm{~h}$, as shown in Fig. 2f. Figure 2g, $\mathrm{h}$ shows a secondary electron SEM micrograph of the 30-h milled powders with the corresponding energy-dispersive spectroscopy (EDS). EDS analysis was carried out several times to semiquantitatively measure the composition of the 30-h milled powder, indicating that the average concentrations of $\mathrm{Fe}, \mathrm{Cr}, \mathrm{Al}, \mathrm{Cu}, \mathrm{Ni}$ and $\mathrm{Si}$ elements are $~ 18.2, \sim 12$ $.1, \sim 11.4, \sim 6.3, \sim 23.1$ and 28.9 at. \%, respectively, generally consistent with the nominal composition (Table 1). The results show that $\mathrm{Fe}_{3} \mathrm{Cr}_{2} \mathrm{Al}_{2} \mathrm{CuNi}_{4} \mathrm{Si}_{5}$ HE-MG powders were successfully prepared.

To maintain the amorphous structure induced by MA, it is preferred to conduct UHPC at a temperature as low as possible. Therefore, the optimum experimental parameters were determined through orthogonal tests as follows: temperature $=300^{\circ} \mathrm{C}$, pressure $=6 \mathrm{GPa}$ and dwell time $=5 \mathrm{~min}$. The XRD patterns of UHPC bulk $\mathrm{Fe}_{3} \mathrm{Cr}_{2} \mathrm{Al}_{2} \mathrm{CuNi}_{4} \mathrm{Si}_{5}$ HE-MG are shown in Fig. 3a. The (011) diffraction peak became sharp, and its half-width decreased, indicating that crystallization occurred in $\mathrm{Fe}_{3} \mathrm{Cr}_{2} \mathrm{Al}_{2} \mathrm{CuNi}_{4} \mathrm{Si}_{5} \mathrm{HE}-\mathrm{MG}$. Figure $3 \mathrm{~b}$ shows the microstructures of bulk $\mathrm{Fe}_{3} \mathrm{Cr}_{2} \mathrm{Al}_{2} \mathrm{CuNi}_{4} \mathrm{Si}_{5}$ HE-MG after UHPC. Some irregular pot holes were dispersed in the matrix alloy, and no clear crystal boundary was observed in $\mathrm{Fe}_{3} \mathrm{Cr}_{2} \mathrm{Al}_{2} \mathrm{CuNi}_{4} \mathrm{Si}_{5}$ HE-MG.

To confirm phase structure of $\mathrm{Fe}_{3} \mathrm{Cr}_{2} \mathrm{Al}_{2} \mathrm{CuNi}_{4} \mathrm{Si}_{5}$ HE-MG, TEM method was used to measure the crystal structure of these phases, as shown in Fig. 3c-f. Figure 3c shows a small amount of tiny nanoparticles, with a size of (10-20) $\mathrm{nm}$ in the bright-field image. The corresponding selected-area electron diffraction (SAED) pattern contains numerous point reflections from crystalline phases; some reflexes are also visible on the main ring (as shown in the inset of Fig. 3d, e). The SAED pattern clearly confirmed that the matrix phase of $\mathrm{Fe}_{3} \mathrm{Cr}_{2} \mathrm{Al}_{2} \mathrm{CuNi}_{4} \mathrm{Si}_{5} \mathrm{HE}-\mathrm{MG}$ had an amorphous structure, as shown in Fig. 3d. Moreover, the results show that these nanocrystals have BCC structure. However, it is pity that a lower scanning resolution 

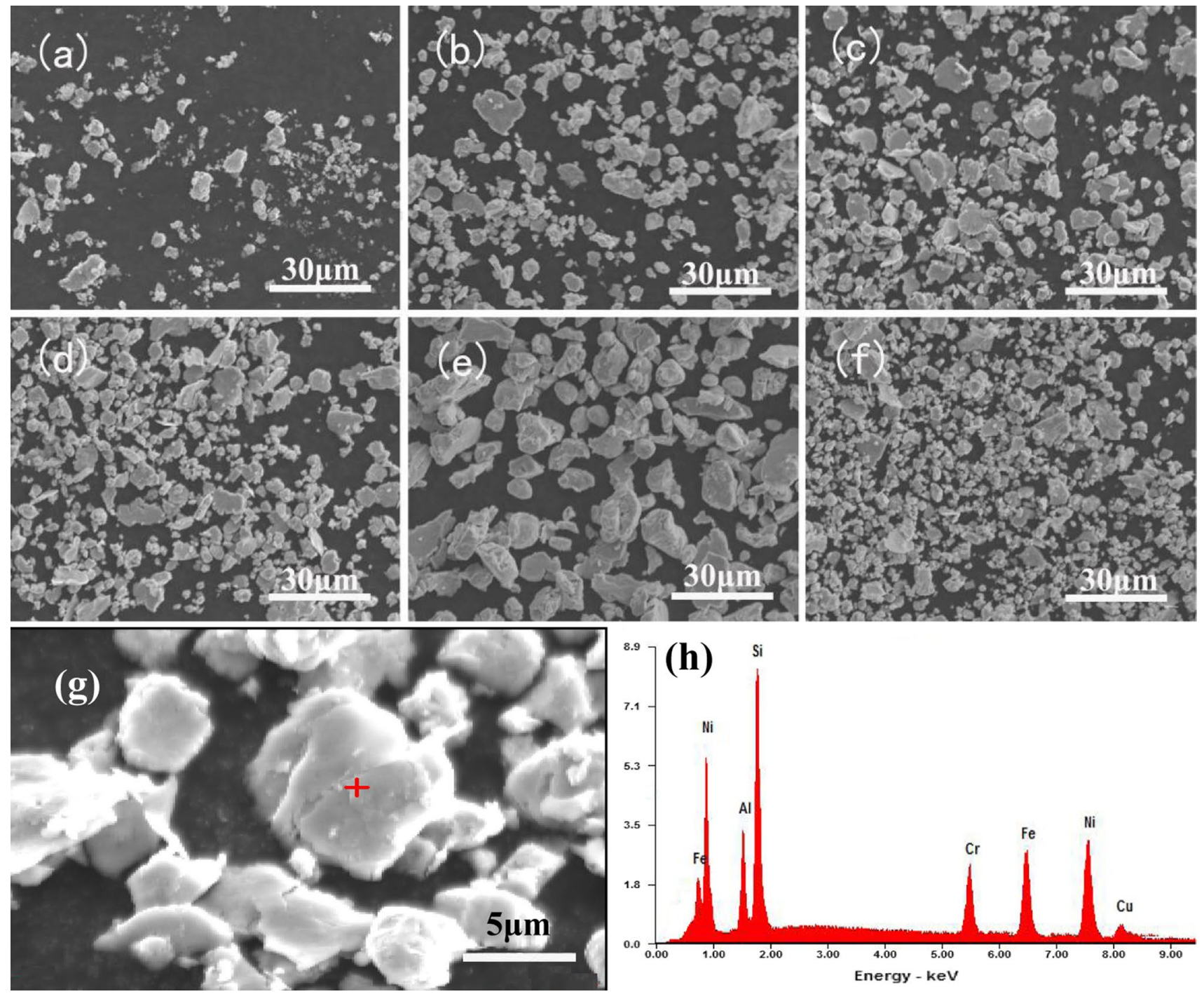

Fig. 2 SEM images of $\mathrm{Fe}_{3} \mathrm{Cr}_{2} \mathrm{Al}_{2} \mathrm{CuNi}_{4} \mathrm{Si}_{5}$ HEA powders milled in different time: a $4 \mathrm{~h}, \mathbf{b} 8 \mathrm{~h}, \mathbf{c} 10 \mathrm{~h}, \mathbf{d} 20 \mathrm{~h}, \mathbf{e} 30 \mathrm{~h}, \mathbf{f} 40 \mathrm{~h}$, g SEM image of the 30-h milled powders and $\mathbf{h}$ EDS spectrum corresponding to $\mathbf{g}$

Table 1 Chemical composition of the $\mathrm{Fe}_{3} \mathrm{Cr}_{2} \mathrm{Al}_{2} \mathrm{CuNi}_{4} \mathrm{Si}_{5}$ powders (at.\%)

\begin{tabular}{lllllll}
\hline Process & $\mathrm{Fe}$ & $\mathrm{Cr}$ & $\mathrm{Al}$ & $\mathrm{Cu}$ & $\mathrm{Ni}$ & $\mathrm{Si}$ \\
\hline $\begin{array}{l}\text { Nominal composi- } \\
\text { tion }\end{array}$ & 17.7 & 11.8 & 11.8 & 5.9 & 23.5 & 29.3 \\
$30 \mathrm{~h} \mathrm{MA}$ & 18.2 & 12.1 & 11.4 & 6.3 & 23.1 & 28.9 \\
\hline
\end{tabular}

limits the component analysis of nanoparticles in the microstructure. Thus, the distribution of elements in the bulk $\mathrm{Fe}_{3} \mathrm{Cr}_{2} \mathrm{Al}_{2} \mathrm{CuNi}_{4} \mathrm{Si}_{5}$ alloy was analyzed by TEM combined with EDS (Fig. 3f). The X-ray energy spectrum analysis shows that the composition elements of $\mathrm{Fe}$, $\mathrm{Cr}, \mathrm{Al}, \mathrm{Cu}, \mathrm{Ni}$ and $\mathrm{Si}$ were uniformly distributed in the matrix. Further analysis shows that the nanoparticles in $\mathrm{Fe}_{3} \mathrm{Cr}_{2} \mathrm{Al}_{2} \mathrm{CuNi}_{4} \mathrm{Si}_{5}$ alloy were richer in Fe. Therefore, the microstructural observation shows that $\mathrm{Fe}_{3} \mathrm{Cr}_{2} \mathrm{Al}_{2} \mathrm{CuNi}_{4} \mathrm{Si}_{5}$
HE-MG is mainly composed of amorphous phase and slight nanocrystals.

\subsection{Mechanical Properties}

The Vickers hardness of $\mathrm{Fe}_{3} \mathrm{Cr}_{2} \mathrm{Al}_{2} \mathrm{CuNi}_{4} \mathrm{Si}_{5}$ HE-MG after UHPC was measured at room temperature. The Vickers hardnesses of $\mathrm{Fe}_{3} \mathrm{Cr}_{2} \mathrm{Al}_{2} \mathrm{CuNi}_{4} \mathrm{Si}_{5} \mathrm{HE}-\mathrm{MG}$ and some typical HEAs of FeCrAlNiX (X=Cu, Co, C) HEA system are 


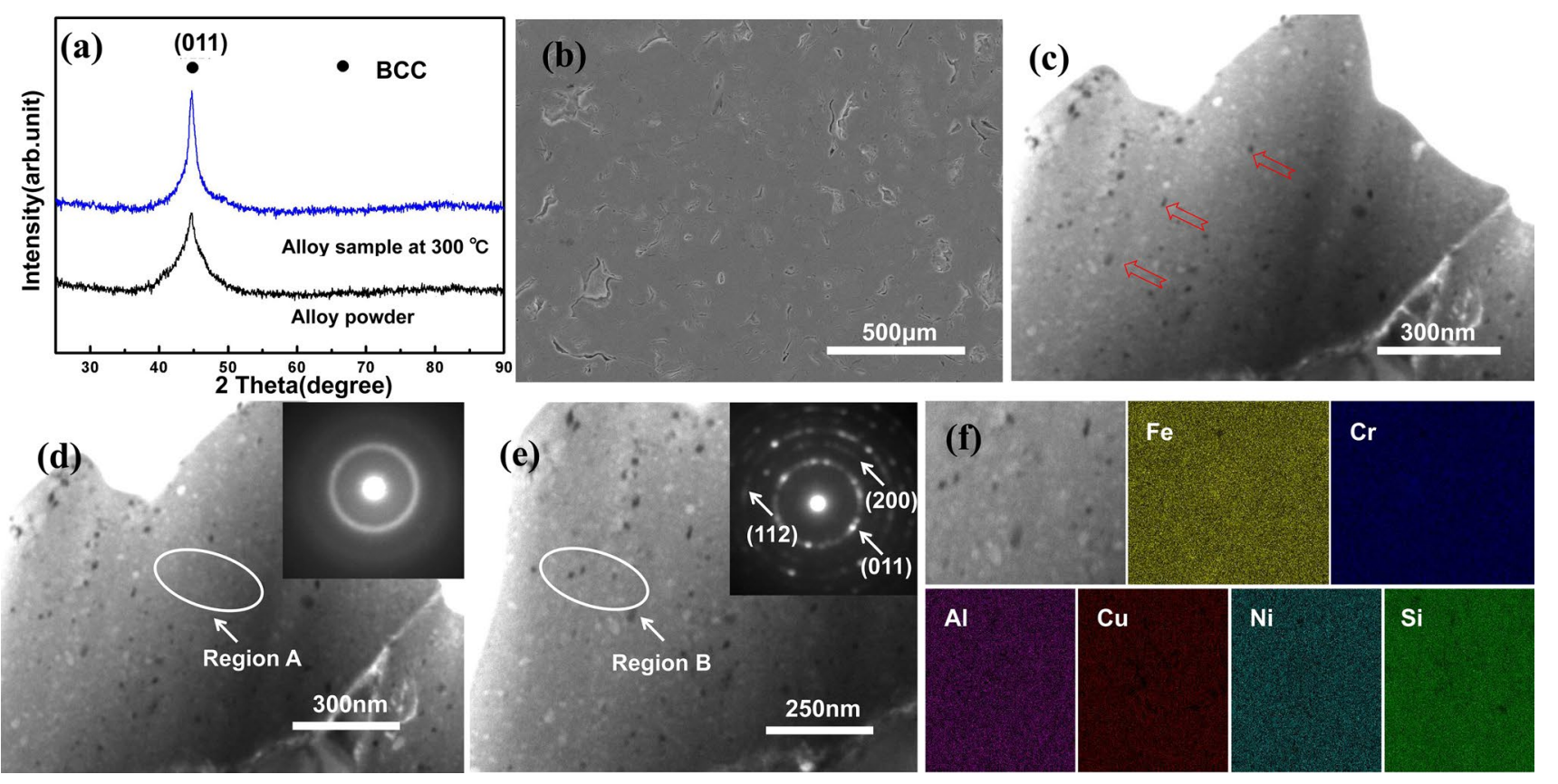

Fig. 3 Microstructural characterizations of $\mathrm{Fe}_{3} \mathrm{Cr}_{2} \mathrm{Al}_{2} \mathrm{CuNi}_{4} \mathrm{Si}_{5}$ HE-MGs: a XRD patterns of the present HE-MG powders and ultrahigh pres-

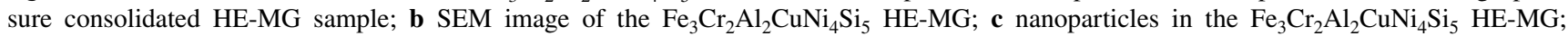
d microstructure of $\mathrm{Fe}_{3} \mathrm{Cr}_{2} \mathrm{Al}_{2} \mathrm{CuNi}_{4} \mathrm{Si}_{5} \mathrm{HE}-\mathrm{MG}$, the inset shows the selected-area diffraction pattern of the matrix; e nanoparticles in the $\mathrm{Fe}_{3} \mathrm{Cr}_{2} \mathrm{Al}_{2} \mathrm{CuNi}_{4} \mathrm{Si}_{5} \mathrm{HE}-\mathrm{MG}$, the inset shows the selected-area diffraction pattern of the nanoparticles; $\mathbf{f}$ TEM-EDS elemental mapping of six principal elements

Table 2 Vickers hardness of HEAs at room temperature

\begin{tabular}{llll}
\hline Alloys & Process & Hardness (Hv) & Refs. \\
\hline $\mathrm{Fe}_{3} \mathrm{Cr}_{2} \mathrm{Al}_{2} \mathrm{CuNi}_{4} \mathrm{Si}_{5}$ & MA+UHPC & 1150 & This work \\
$\mathrm{Fe}_{25} \mathrm{Al}_{7.5} \mathrm{Cu}_{17.5} \mathrm{Ni}_{25} \mathrm{Co}_{25}$ & SPS & 454 & {$[9]$} \\
$\mathrm{FeCrAl}_{0.9} \mathrm{NiCo}$ & Arc-melting & 527 & {$[15]$} \\
$\mathrm{FeCrAl}_{0.5} \mathrm{NiCo}_{0.3} \mathrm{C}_{0.2}$ & SPS & 617 & {$[23]$} \\
\hline
\end{tabular}

shown in Table 2. The listed HEAs were prepared following traditional preparation methods (casting and spark plasma sintering) except $\mathrm{Fe}_{3} \mathrm{Cr}_{2} \mathrm{Al}_{2} \mathrm{CuNi}_{4} \mathrm{Si}_{5}$ HE-MG studied in this paper. Obviously, $\mathrm{Fe}_{3} \mathrm{Cr}_{2} \mathrm{Al}_{2} \mathrm{CuNi}_{4} \mathrm{Si}_{5}$ HE-MG exhibited the highest hardness $(\sim 1150 \mathrm{Hv})$ of all the HEAs listed in Table 2. The high hardness of $\mathrm{Fe}_{3} \mathrm{Cr}_{2} \mathrm{Al}_{2} \mathrm{CuNi}_{4} \mathrm{Si}_{5} \mathrm{HE}-\mathrm{MG}$ is probably because of the formation of amorphous phase and the nanosized precipitates as well as solid-solution strengthening [32-34]. Notably, nanosized precipitates significantly strengthen the alloy. A recent study of an amorphous/ nanocrystalline structure indicates that the nanosized precipitates mixed in the MG matrix can effectively hinder the propagation of shear bands during plastic deformation [35, 36], contributing to hardening and countering the softening effect of shear band. Thus, the resulting $\mathrm{Fe}_{3} \mathrm{Cr}_{2} \mathrm{Al}_{2} \mathrm{CuNi}_{4} \mathrm{Si}_{5}$ HE-MG actually has a higher hardness than other typical HEAs of FeCrAlNi $(\mathrm{Cu}, \mathrm{Co}, \mathrm{C}) \mathrm{HEA}$ system.

\subsection{Corrosion Resistance}

The corrosion behavior of $\mathrm{Fe}_{3} \mathrm{Cr}_{2} \mathrm{Al}_{2} \mathrm{CuNi}_{4} \mathrm{Si}_{5} \mathrm{HE}-\mathrm{MG}$ and 304 stainless steel (contrast sample) samples in $3.5 \% \mathrm{NaCl}$ solution was investigated by electrochemical measurements. The potentiodynamic polarization curves of the two alloys are shown in Fig. 4. Figure 4a shows that the corrosion potential of $\mathrm{Fe}_{3} \mathrm{Cr}_{2} \mathrm{Al}_{2} \mathrm{CuNi}_{4} \mathrm{Si}_{5}$ HE-MG shifted positively compared with that of 304 stainless steel, approximately from $-0.34 \mathrm{~V}$ to $-0.19 \mathrm{~V}$, and the corrosion current density decreased significantly, approximately from $2 \times 10^{-5}$ to $4 \times 10^{-6} \mathrm{~A}$. The Nyquist plot obtained from EIS measurements for $\mathrm{Fe}_{3} \mathrm{Cr}_{2} \mathrm{Al}_{2} \mathrm{CuNi}_{4} \mathrm{Si}_{5}$ HE-MG and 304 stainless steel after 30 -min immersion in 3.5\% $\mathrm{NaCl}$ solution is shown in Fig. 4b. The plot was characterized by a depressed semicircle from high frequencies to medium frequencies. The semicircle diameter of $\mathrm{Fe}_{3} \mathrm{Cr}_{2} \mathrm{Al}_{2} \mathrm{CuNi}_{4} \mathrm{Si}_{5}$ HE-MG is four times higher than that of 304 stainless steel. Therefore, these EIS results show that $\mathrm{Fe}_{3} \mathrm{Cr}_{2} \mathrm{Al}_{2} \mathrm{CuNi}_{4} \mathrm{Si}_{5}$ HE-MG has a higher corrosion resistance than 304 stainless steel.

The extraordinary corrosion resistance of $\mathrm{Fe}_{3} \mathrm{Cr}_{2} \mathrm{Al}_{2} \mathrm{CuNi}_{4} \mathrm{Si}_{5}$ HE-MG will be discussed now. Previous studies showed that the constituent elements significantly affect the corrosion resistance of alloy. Shang et al. [37] found that addition of $\mathrm{Cr}$ to $\mathrm{NiCo}$ and $\mathrm{NiCoFe}$ can form massive $\mathrm{Cr}_{2} \mathrm{O}_{3}$; these $\mathrm{Cr}_{2} \mathrm{O}_{3}$ can protect the matrix effectively 

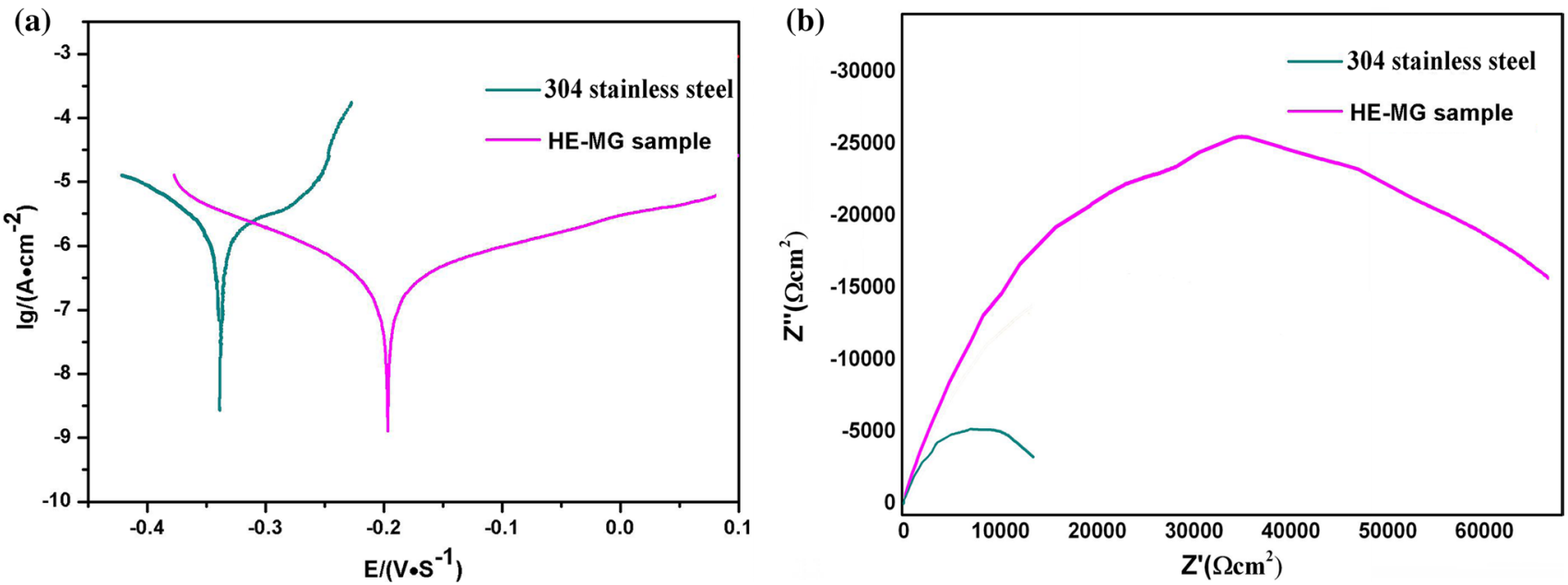

Fig. 4 Electrochemical measurement of $\mathrm{Fe}_{3} \mathrm{Cr}_{2} \mathrm{Al}_{2} \mathrm{CuNi}_{4} \mathrm{Si}_{5} \mathrm{HE}-\mathrm{MGs}$ in 3.5\% $\mathrm{NaCl}$ solution: a potentiodynamic polarization curves of $\mathrm{Fe}_{3} \mathrm{Cr}_{2} \mathrm{Al}_{2} \mathrm{CuNi}_{4} \mathrm{Si}_{5}$ HE-MG and 304 stainless steel; $\mathbf{b}$ Nyquist plots of $\mathrm{Fe}_{3} \mathrm{Cr}_{2} \mathrm{Al}_{2} \mathrm{CuNi}_{4} \mathrm{Si}_{5} \mathrm{HE}-\mathrm{MG}$ and 304 stainless steel

when chloride ions are eroded at a higher potential. Similarly, $\mathrm{Ni}$ and $\mathrm{Al}$ play a similar role in inhibiting alloy dissolution. Therefore, the $(\mathrm{Cr}, \mathrm{Ni}, \mathrm{Al})$-containing alloys, even MGs, usually exhibit excellent corrosion resistance in $\mathrm{Cl}$ ion-containing solutions. In this study, the corrosion resistances of the constituent elements in $\mathrm{Fe}_{3} \mathrm{Cr}_{2} \mathrm{Al}_{2} \mathrm{CuNi}_{4} \mathrm{Si}_{5}$ HE-MG were significantly different. On the surface of $\mathrm{Fe}_{3} \mathrm{Cr}_{2} \mathrm{Al}_{2} \mathrm{CuNi}_{4} \mathrm{Si}_{5}$ HE-MG, $\mathrm{Cr}$, Ni and $\mathrm{Al}$ probably exist in the form of $\mathrm{Cr}_{2} \mathrm{O}_{3}, \mathrm{NiCl}_{2}$ and $\mathrm{Al}_{2} \mathrm{O}_{3}$, respectively, and they are highly stable in a neutral solution and in an acid solution. Moreover, the effect of alloying synergistic function and barrier function should be considered. When $\mathrm{Fe}_{3} \mathrm{Cr}_{2} \mathrm{Al}_{2} \mathrm{CuNi}_{4} \mathrm{Si}_{5}$ HE-MG is corroded, the oxide of element with better corrosion resistance will cover the total surface to prevent further corrosion. Therefore, the exceptional corrosion resistance properties of $\mathrm{Fe}_{3} \mathrm{Cr}_{2} \mathrm{Al}_{2} \mathrm{CuNi}_{4} \mathrm{Si}_{5}$ HE-MG in this present study are related to the $\mathrm{Ni}, \mathrm{Cr}$ and $\mathrm{Al}$ elements and the relative homogeneous microstructure, facilitating the formation of protective passive films and improving the corrosion resistance.

\section{Conclusion}

A novel non-equiatomic senary $\mathrm{Fe}_{3} \mathrm{Cr}_{2} \mathrm{Al}_{2} \mathrm{CuNi}_{4} \mathrm{Si}_{5} \mathrm{HE}-\mathrm{MG}$ (at.\%) was successfully manufactured via a MA and UHPC technique that enabled the formation an amorphous structure. The resulting $\mathrm{Fe}_{3} \mathrm{Cr}_{2} \mathrm{Al}_{2} \mathrm{CuNi}_{4} \mathrm{Si}_{5}$ HE-MG exhibited outstanding properties, in terms of both corrosion resistance and hardness. The findings suggest that non-equiatomic HEMGs can also be obtained based on the statistical analysis of phase selection rules and similar element replacement principle. It is expected that the proposed alloy design strategy would be equally effective for the preparation of other HE-MG materials.

Acknowledgements The work was financially supported by the Fundamental Research Funds for the Central Universities. We also thank the Instrument Analysis Center of Xi' an Jiaotong University for providing characterization analysis.

\section{References}

[1] Y.X. Zhuang, J. Chen, P.W. Wang, J.C. He, Acta Metall. Sin. (Engl. Lett.) 24, 4 (2011)

[2] D. Cao, Y. Wu, H. Wang, X.J. Liu, Z.P. Lu, Acta Metall. Sin. (Engl. Lett.) 29, 2 (2016)

[3] H. Wang, S.G. Xiao, T. Zhang, Q. Xu, Acta Metall. Sin. (Engl. Lett.) 29, 6 (2016)

[4] A. Inoue, K. Ohtera, A.P. Tsai, T. Masumoto, J. Appl. Phys. 27, 4 (1988)

[5] C. Suryanarayana, A. Inoue, Int. Mater. Rev. 58, 3 (2013)

[6] J.W. Li, L.J. Yang, H.R. Ma, K.M. Jiang, Int. J. Mod. Phys. B 31, 16 (2017)

[7] M. Madinehei, P. Bruna, M.J. Duarte, E. Pineda, J. Klemm, F.U. Renner, J. Alloys Compd. 615, 128 (2014)

[8] T. Xu, S.J. Pang, T. Zhang, J. Alloys Compd. 625, 15 (2015)

[9] L. He, S. Zhang, J. Sun, C.J. Zhang, Trans. Nonferrous Met. Soc. China 16, 992 (2006)

[10] H.W. Xu, Y.L. Du, Y. Deng, Trans. Nonferrous Met. Soc. China 22, $842(2012)$

[11] S.Y. Wang, W. Jiang, H.D. Hu, P.F. Liu, Prog. Nat. Sci.: Mater. 27, 503 (2017)

[12] R. Wei, J. Tao, H. Sun, C. Chen, G.W. Sun, F.S. Li, Mater. Lett. 197, 87 (2017)

[13] A. Takeuchi, N. Chen, T. Wada, Y. Yokoyama, H. Kato, A. Inoue, J.W. Yeh, Intermetallics 19, 1546 (2011)

[14] Z.Q. Fu, W.P. Chen, H.M. Wen, D.L. Zhang, Z. Chen, B.L. Zheng, Y.Z. Zhou, E.J. Lavernia, Acta Mater. 107, 59 (2016)

[15] F.J. Wang, Y. Zhang, G.L. Chen, Int. J. Mod. Phys. 23, 1254 (2009)

[16] N. Kumagai, A. Kawashima, Appl. Electrochem. 16, 565 (1986) 
[17] D.C. Ma, M.J. Yao, K.G. Pradeep, C.C. Tasan, H.K. Springer, D. Raabe, Acta Mater. 98, 288 (2015)

[18] M.J. Yao, K.G. Pradeep, C.C. Tasan, D. Raabe, Scr. Mater. 72, 5 (2014)

[19] Y. Zhou, X. Jin, L. Zhang, X.Y. Du, B.S. Li, Mater. Sci. Eng., A 716, 235 (2018)

[20] S.Z. Wei, J.H. Zhu, L.J. Xu, R. Long, Mater. Des. 27, 58 (2006)

[21] S. Mridha, S. Samal, P.Y. Khan, K. Biswas, Metall. Mater. Trans. A 44, 4532 (2013)

[22] S. Yadav, S. Sarkar, A. Aggarwal, A. Kumar, K. Biswas, Wear 410, 93 (2018)

[23] Y. Zhang, Y.J. Zhou, J.P. Lin, G.L. Chen, P.K. Liaw, Adv. Eng. Mater. 10, 534 (2008)

[24] S. Guo, Q. Hu, C. Ng, C.T. Liu, Intermetallics 41, 96 (2013)

[25] S. Guo, C.T. Liu, Prog. Nat. Sci. Mater. Int. 21, 433 (2011)

[26] A.L. Greer, Nature 366, 303 (1993)

[27] A. Takeuchi, A. Inoue, Mater. Trans. 46, 2817 (2005)

[28] S.C. Fang, W.P. Chen, Z.Q. Fu, Mater. Des. 54, 973 (2014)
[29] M.L. Trudeau, R. Schultz, D. Dussault, A. Van Neste, Phys. Rev. Lett. 64, 1 (1990)

[30] U. Patil, S.J. Hong, C. Suryanarayana, J. Alloys Compd. 389, 1 (2005)

[31] N.A. Aqeeli, C. Suryanarayana, M.A. Hussein, J. Appl. Phys. 114, $153512(2013)$

[32] B. Gwalani, S. Gorsse, D. Choudhuri, M. Styles, Y.F. Zheng, R.S. Mishra, R. Banerjee, Acta Mater. 153, 169 (2018)

[33] H. Shahmir, E. Tabachnikova, A. Podolskiy, M. Tikhonovsky, T.G. Langdon, Mater. Sci. Eng. 53, 11813 (2018)

[34] K. Ma, H.M. Wen, T. Hu, T.D. Topping, D. Isheim, D.N. Seidman, E.J. Lavernia, J.M. Schoenung, Acta Mater. 62, 141 (2014)

[35] G. Wu, K.C. Chan, L. Zhu, L. Sun, J. Lu, Nature 545, 80 (2017)

[36] T. Yue, Y.Q. Wang, J.Y. Zhang, K. Wu, G. Li, J. Kuang, G. Liu, J. Sun, Nanoscale 10, 14331 (2018)

[37] X.L. Shang, Z.J. Wang, F. He, J.C. Wang, J.J. Li, J.K. Yu, Sci. China Technol. Sci. 61, 189 (2018) 